\title{
Local Action Group - a pillar of the development of the Romanian village
}

\author{
Mihaela Felicia (Stanciu) Florescu ${ }^{1}$, and Adrian Turek Rahoveanu ${ }^{1, *}$ \\ ${ }^{1}$ University of Agronomic Sciences and Veterinary Medicine of Bucharest, 59 Marasti Blvd, \\ Bucharest, Romania
}

\begin{abstract}
The Local Action Groups have the capacity to act in a complex way, so as to cover the entire economic and social issues of the regions where they act. The actions carried out by the LAGs have direct consequences on rural development by encouraging those projects that develop alternative solutions in obtaining revenues; diversification of the market for products and services; ensuring sustainable development, by protecting the environment and ensuring the security and well-being of life. This article makes an analysis of the impact of European funding in supporting the development of the rural environment of the area of influence of a Local Action Group in Olt County. It describes the situation of European funding at LAG level and the proposal of development directions that need to be considered in the future: increasing competitiveness in agricultural activities, sustainable use of resources and balanced development of economic activities and local communities in rural areas.
\end{abstract}

Keywords: rural development, competitiveness, sustainability, Local Action Group

JEL Classification: $Q 01 ; Q 15 ; Q 18$;

\section{Introduction}

In the European Union about $90 \%$ of its territory is found in rural areas, also living here more than half of the European population. The Rural Development Program has been a very important component of the Common Agricultural Policy, promoting the sustainable development of rural areas in Europe and addressing socio-economic and environmental issues. [8].

In recent years, sustainable rural development has become a hot topic in rural areas due to the complex interactions between natural resources, agricultural production and local communities. [5, 12].

The Common Agricultural Policy (CAP) is a partnership between agriculture and society, between Europe and its farmers. The CAP aims to: support farmers and improve agricultural productivity; to protect farmers in the European Union so that they can ensure a decent living; to contribute to the fight against climate change and the sustainable management of natural resources; to preserve rural areas throughout its territory; maintain

\footnotetext{
*Corresponding author: turek.adrian@managusamv.ro
} 
the competitiveness of the rural economy by promoting jobs in the agricultural sector and its upstream and downstream sectors $[13,1]$.

The CAP is a common ground for all EU member states. It is coordinated and funded at Union level from the EU budget. The financing of agricultural policies is based on two funds, namely: for market measures, payments are made through the European Agricultural Guarantee Fund (EAGF) and rural development programs are carried out through funding provided by the European Agricultural Fund for Rural Development ( EAFRD) [9].

Through the Rural Development Fund, the EU aimed to support Member States in developing rural areas in order to reduce existing socio-economic gaps [6]. This fund is the second pillar of the CAP, the first pillar being the one that grants direct payments to farmers. [7].

Under the development pillar, the LEADER Axis is applied to all Member States through the National Rural Development Programs.

Through these national rural development programs, each EU Member State attracts the financial resources allocated by the EU for agriculture and rural development, which is structured in priority axes, each addressing a specialized area of intervention. The LEADER program is Axis 4 of the RDP, but differs from it in its specific approach. [14, 15].

Since the advent of Axis 4 (LEADER axis), whose name was chosen from the expression that characterizes it: "Links between rural development actions", it has had an innovative vision on the implementation of rural development policies, namely : involvement of local partners in decision-making, in order to establish the steps to be taken for the future development of the area in which they live. [3, 16]. Subsequently, the LEADER axis brought a number of positive changes in rural areas and played an innovative role in solving problems in rural space [4].

The LEADER Axis aims to offer rural residents the opportunity to take the initiative and get proactively involved in implementing and then implementing rural development strategies at the local level to increase the quality of life and standard of living.. [11, 2, 10].

\section{Methods}

As working methodology, the method of direct observation, comparative analysis and case study conducted within the Local Action Group "Vedea - Gavanu - Burdea" was used. This article aims to study the existing opportunities within the NRDP at the level of Romania, regarding the second pillar: "rural development", as a support element for increasing the economic competitiveness of rural areas.

\section{Results and Discussions}

Existing rural development programs in all EU Member States pursue actions and budget allocation for the development of their specific territories. In this way, European policy for rural development aims to provide support for the implementation of rural development actions at local, regional or even national level.

Each EU Member State receives a budget allocation through the National Rural Development Programs of each Member State, in order to implement projects and investments that contribute to the implementation of rural development objectives in that territory.

Within the RDP, the LEADER axis was encouraged in order to increase the development potential of the rural area, by capitalizing on local initiatives, by the possibility of acquiring knowledge on local development and by popularizing them in other rural areas. 
The creation of local associations, under the name of "Local Action Groups (LAGs)" is an original feature of the LEADER approach.

This partnership applies SWOT analysis to identify the key elements that will be included in the future development strategy, to which it will allocate the available budget. Thus, the LAG has the task of managing the financial resources in order to guarantee the development of the territory it represents.

In the current programming period 2014-2020, the LAGs could be set up through submeasure 19.1 - which provided support for the preparation of public-private partnerships in order to develop local development strategies - which was launched in 2015. The budget allocated to this sub-measure was 2.4 million euros and was used in a proportion of $99.1 \%$ (2,379 million euros). 179 projects were submitted, of which 175 were declared eligible and selected for funding.

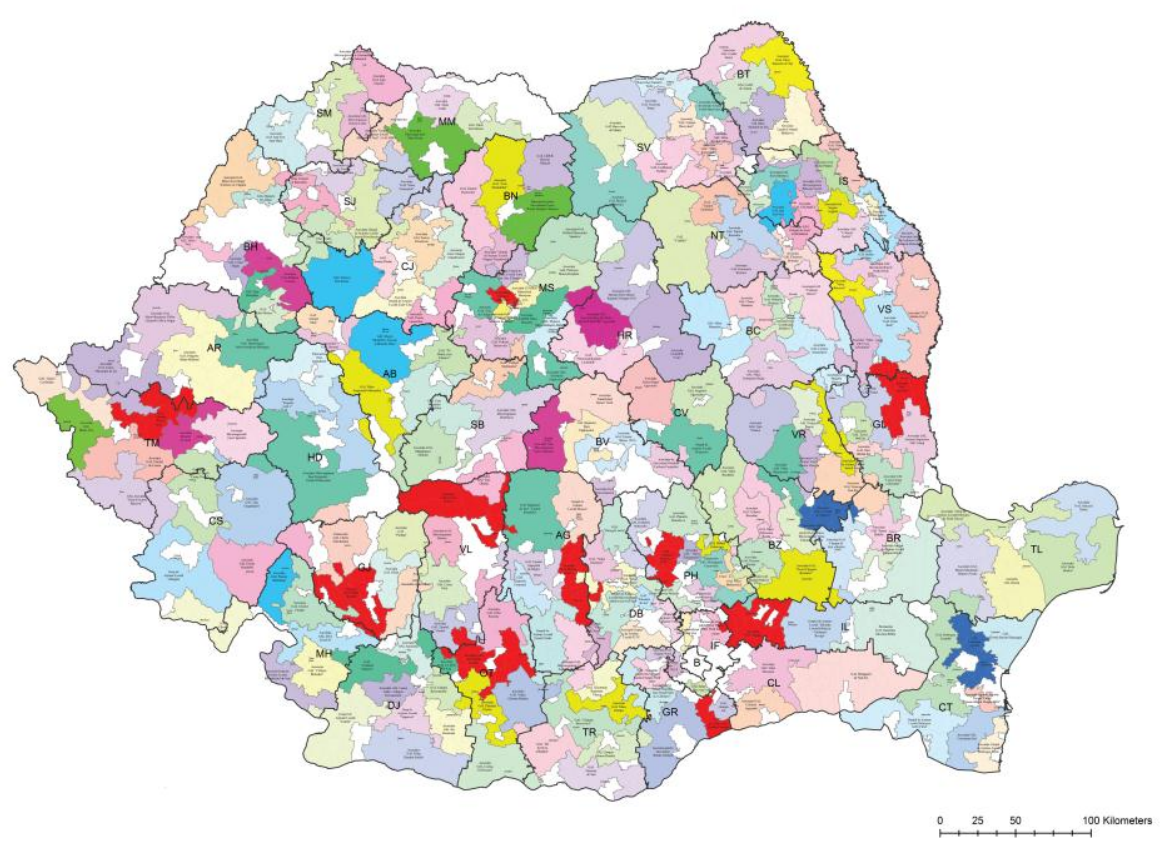

Fig. 1. Local Action Groups (2014-2020)

Source: https://www.rndr.ro/leader.html

In order to follow the way in which the LEADER Program was implemented, how a LAG is established and operates, as well as the impact that this public-private partnership has on the life of the rural community, we chose a case study, relevant for the analyzed region: LAG "Vedea - Gavanu - Burdea".

The Local Action Group "Vedea - Găvanu - Burdea" was established in the programming period 2007-2013 and even if it benefited from LEADER funding to implement a series of projects at the territorial level, the local development capacity reached did not respond to local needs and consequently the activity of this LAG continued for the 2014-2020 programming period.

The difficulties that the LAG territory encountered were: the aging trend of the population, the lack of employment opportunities, the large discrepancy with the degree of development of urban areas, the degree of fragmentation of small farmers' lands and their 
lack of financing for penetration to the market, the lack of agricultural equipment and the moral wear and tear of the existing ones, the lack of specialized agricultural knowledge among farmers, the existence of different marginalized communities or at risk of poverty.

The territory covered by the potential of the Local Action Group "Vedea Găvanu Burdea" includes 19 localities, of which 18 are part of Olt County (Drăgănești-Olt and the communes Coteana, Crâmpoia, Dăneasa, Ghimpețeni, Gostăvățu, Izvoarele, Măriești, Nicolae Titulescu, Radomirești, Schitu, Seaca, Șerbănești, Stoicănești, Vâlcele and Văleni), and a locality - Dobrotești - is part of Teleorman County.

Taking into account the recommended indices on component A, respectively 985.37 Euro / $\mathrm{km}^{2}$ and 19.84 Euro / inhabitant, on the one hand, and the area and population of the LAG "Vedea - Găvanu - Burdea", on the other hand, the allocation allocated to this LAG was $2,317,360$ euros.

The value related to the quality level (Component B) obtained following the evaluation and selection process was 679,550.31 euros.

Subsequently, following the supplementation of the SDL financial allocation, following the approval of the Report on the result of the SDL evaluation, the financial allocation of the LAG was increased by $128,759.03$ euros.

Table 1. Financial allocation of the "Vedea - Găvanu - Burdea" LAG

\begin{tabular}{|c|c|c|c|c|}
\hline Specification & $\begin{array}{c}\text { Surface } \\
\left(\mathrm{km}^{2}\right)\end{array}$ & Population & $\begin{array}{c}\text { Inhabitants } \\
/ \mathrm{km}^{2}\end{array}$ & $\begin{array}{c}\text { Financial allocation } \\
(\text { euros })\end{array}$ \\
\hline Component A & $1.084,98$ & 62.916 & 57,98 & 2.317 .360 \\
\hline Component B & - & - & - & $679.550,31$ \\
\hline $\begin{array}{c}\text { SDL financial } \\
\text { supplement }\end{array}$ & - & - & - & $128.759,03$ \\
\hline TOTAL & & & & $3,125.669,34$ \\
\hline
\end{tabular}

Source: http://www.galvgb.ro/

One of the main advantages of a local action group in a region is to focus, together with the actors that make it up, on the problems of that territory and to be able to make guides of the proposed measures in order to solve the identified needs. in the territory of the LAG.

For the correct identification of the needs of the members of the LAG "Vedea - Găvanu - Burdea" it is necessary an assessment at the level of the community within the LAG, of the economic agents in this region, of the local public administration, as well as of the active members of the LAG existing.

The community has an important role in determining the needs, but also the strategic directions of local development of micro-regions, as only those who live here can identify these needs because they face them daily.

Following the consultations carried out by the Local Action Group "Vedea - Găvanu Burdea" with all important actors in the territory, based on the diagnostic analysis and SWOT analysis, were identified the objectives, priorities, areas of intervention and measures that were introduced in within the LAG's Local Development Strategy.

The "Vedea - Găvanu - Burdea" LAG chose to grant funding for 3 priorities, aiming at no less than 9 measures, allocating approximately 39.7 euro / inhabitant, respectively $2,304.68$ euro $/ \mathrm{km}^{2}$. 
Table 2. Financial plan divided by priorities of the LAG "Vedea - Găvanu - Burdea"

\begin{tabular}{|c|c|c|c|}
\hline Priority & Measure & $\begin{array}{l}\text { Financial } \\
\text { resources } \\
\text { (euros) }\end{array}$ & $\begin{array}{l}\text { The amount } \\
\text { allocated } \\
(\%)\end{array}$ \\
\hline \multirow{4}{*}{$\begin{array}{l}\text { P6 - "Promoting social } \\
\text { inclusion, poverty } \\
\text { reduction and economic } \\
\text { development in rural } \\
\text { areas"“ }\end{array}$} & $\begin{array}{l}\text { M7 / 6B Village } \\
\text { development }\end{array}$ & $1.058 .130,09$ & 33,85 \\
\hline & $\begin{array}{l}\text { M6 / 6A Development of } \\
\text { the non-agricultural sector }\end{array}$ & 680.836 & 21,78 \\
\hline & $\begin{array}{l}\text { M8 / 6B Social } \\
\text { infrastructure for } \\
\text { marginalized / at-risk-of- } \\
\text { poverty / social exclusion } \\
\text { communities }\end{array}$ & 100.000 & 3,20 \\
\hline & $\begin{array}{l}\text { M9 / 6A Support for the } \\
\text { creation of new economic } \\
\text { activities in the non- } \\
\text { agricultural sector }\end{array}$ & 35.000 & 1,12 \\
\hline TOTAL P6 & & $1.873 .966,09$ & 59,95 \\
\hline \multirow{4}{*}{$\begin{array}{l}\mathrm{P} 2-\text { „Increase farm } \\
\text { viability and } \\
\text { competitiveness of all } \\
\text { types of agriculture in all } \\
\text { regions and promote } \\
\text { innovative agricultural } \\
\text { technologies and } \\
\text { sustainable forest } \\
\text { management" }\end{array}$} & $\begin{array}{l}\text { M4 / 2B Renewal of } \\
\text { generations of farmers }\end{array}$ & 240.000 & 7,68 \\
\hline & $\begin{array}{l}\text { M2 / 2A Development of } \\
\text { agricultural holdings }\end{array}$ & $331.968,67$ & 10,62 \\
\hline & $\begin{array}{l}\text { M3 / 2A Supporting small } \\
\text { farms }\end{array}$ & 10.000 & 0,32 \\
\hline & $\begin{array}{l}\text { M5 / 2A Supporting } \\
\text { legally constituted } \\
\text { associative forms }\end{array}$ & $22.600,35$ & 0,72 \\
\hline TOTAL P2 & & $604.569,02$ & 19,34 \\
\hline $\begin{array}{l}\text { P1 - „Encourage } \\
\text { knowledge transfer and } \\
\text { innovation in agriculture, } \\
\text { forestry and rural areas“" }\end{array}$ & $\begin{array}{l}\text { M1 / 1C Vocational } \\
\text { training of actors involved } \\
\text { in the agricultural sector }\end{array}$ & $22.000,37$ & 0,70 \\
\hline TOTAL P1 & & $22.000,37$ & 0,70 \\
\hline TOTAL PRIORITIES & & $2.500 .535,48$ & 80,00 \\
\hline \multicolumn{2}{|c|}{ Operating and animation costs for SDL } & $625.133,86$ & 20,00 \\
\hline TOTAL GENERAL & & $3.125 .669,34$ & 100,00 \\
\hline
\end{tabular}

Sursa: http://www.galvgb.ro/

The local development strategy of the Local Action Group "Vedea - Găvanu - Burdea" through the measures introduced in it, contributes to the mission of the Europe 2020 Strategy, by promoting sustainable rural development within the LAG territory, obtaining a more balanced agricultural sector in terms of territorial and ecological, more beneficial for the climate, more resilient, more competitive and more innovative. 


\section{Conclusions}

Rural development is a very important issue in the European Union and is currently promoted by the EAFRD.

The role of LAGs is a major one in improving rural development, with regard to increasing the competitiveness of agriculture and forestry, the natural and rural environment, as well as the quality of life and the management of economic activities in rural areas.

Under these conditions, the LAGs, through the local development strategies they implement, offer an integrated management solution, which is related to the following objectives: diversification of traditional agricultural activities; the multifunctionality of agriculture in terms of landscape use and the improvement of cultural and historical heritage; improving food security and promoting local food; involving the local community in preserving social and cultural traditions; employment and income generation in agriculture.

The LEADER program represents for the territory the Local Action Group "Vedea Găvanu - Burdea" not only a set of measures that are implemented through the Local Development Strategy, but is a method of mobilization and promotion of the development of the territory and local communities living here, a tool that works efficiently by adapting decisions on the rural environment to the needs identified within the territory.

\section{References}

1. Bhakar, R., Banafar, K.N.S., Singh, N.P., Gauraha, A.K., 2007. Income and Employment Pattern in Rural Area of Chhattisgarh: A Mircro View. Agricultural Economics Research Association (India), vol. 20(2), 395-406

2. Dargan, L., Shucksmith, M. (2008), LEADER and innovation. Sociologia Ruralis. Volume 48, Issue 3, p. 274-291

3. Esparcia J., Escribano J., Javier S. (2015), From development to power relations and territorial governance: Increasing the leadership role of LEADER Local Action Groups in Spain, Journal of Rural Studies, vol. 42, pp. 29-42

4. Kovách, I. (2000), LEADER, a new social order, and the Central-and East-European countries. Sociologia Ruralis Volume 40, Issue 2, p. 181-189

5. Pasakarnis, G., Morley, D., Maliene, V. (2013). Rural development and challenges establishing sustainable land Eastern European countries use in Eastern European Countries. Land Use Policy Journal 30, 703-710

6. Talmaciu M., Mihai C. (2004). Politica de dezvoltare rurală durabilă a Uniunii Europene - o nouă abordare. Analele științifice ale Universității "Alexandru Ioan Cuza" din Iași, Vol. Științe Economice, p. 463-468

7. Tomova M., Rezessy A., \& Lenkowski A., Maincent E. (2013). EU governance and EU funds - testing the effectiveness of EU funds in a sound macroeconomic framework. European Economy - Economic Papers 2008 - 2015 510, Directorate General Economic and Financial Affairs (DG ECFIN), European Commission

8. Van der Ploeg, J. D., Renting, H., Brunori, G., Knickel, K., Mannion, J., \& Marsden, T. (2000). Rural Development: From Practices and Policies towards Theory. Sociologia Ruralis Journal, 40(4), 391-408 
9. Baldock, D., Dwyer, J., Lowe, P., Petersen, J., Ward, N. (2001). The Nature of Rural Development: Towards a Sustainable Integrated Rural Policy in Europe. Synthesis Report. IEEP Publisher

10. Csurgó B., Kovách I. (2015) The LEADER Programme in Hungary-Bottom-Up Development with Top-Down Control? Chapter 4 of the Book: Evaluating the European Approach to Rural Development: Grass-roots Experiences of the LEADER Programme. Ashgate Publishing

11. McCabe A., Phillimore J. (2017), Community Groups in Context: Local Activities and Actions (Third Sector Research Series). Policy Press Publisher

12. Mennella, V.G.G. (2006). Greenway Per Lo Sviluppo Sostenibile Del Territorio. Il Verde Editoriale

13. De Noronha Vaz, T., Nijkamp, P., Rastoin, J.L. (2009). Traditional Food Production and Rural Sustainable Development. A European Challenge. Routledge Publischer.

14. Florescu M. F., Turek-Rahoveanu A. (2019). Local Development Strategy: A Key Element of Rural Development: Proceedings of the The 33rd International Business Information Management (IBIMA) Conference, Granada Spain

15. Podaru A. M., Florescu M. F., Turek-Rahoveanu A. (2018). The Local Action Groups Key Actors of the Rural Development. Proceedings of the The 32nd International Business Information Management (IBIMA) Conference Seville Spain

16. Turek-Rahoveanu A. (2012) "LEADER approach" - an opportunity for rural development. Proceedings of the Agrarian Economy and Rural Development - Realities and Perspectives for Romania Conference (AERD'12). Volume 3, Issue 2012 